\title{
Tracking Environmental Sustainability Performance of Public Universities in Kenya
}

\author{
David N. Mungai \\ Wangari Maathai Institute for Peace and Environmental Studies, College of Agriculture and Veterinary Sciences, \\ University of Nairobi, Kenya
}

Copyright $(\mathrm{C} 2017$ by authors, all rights reserved. Authors agree that this article remains permanently open access under the terms of the Creative Commons Attribution License 4.0 International License

\begin{abstract}
Environmental Sustainability Performance Contract (PC) targets were introduced in the 2012/13 financial year as part of the broader public sector reforms and a strategy for performance improvement in the public service that includes Kenyan public universities. However, no evaluation has been conducted to assess performance improvement and impact. The objectives of this study were to; assess the PC targets reporting by public universities in Kenya; assess the authenticity of reporting; establish key challenges in mainstreaming environmental sustainability recommendations; develop an indicative list of environmental sustainability indicators for universities and, compile resources to guide the universities during implementation of environmental sustainability activities and reporting. Data and information were obtained from quarterly reports submitted to the National Environment Management Authority (NEMA) for the 2012/15 period. Proposed indicators were developed from the NEMA guidelines, published sources and online "best practices". Reporting trends revealed an average response rate of $60.2 \%$. The choice of targets was variable, with most universities opting for "soft targets". The top four preferred targets were tree planting (72.7\%), developing environmental policy and creating environmental awareness programs (63.6\% each), and working with stakeholders to protect and conserve the environment (45.4\%). The Vice-Chancellors signed the quarterly reports, confirming authenticity and process ownership. There was no evidence of progressive improvements. Intervention impacts could not be ascertained due to lack of baselines. Key challenges encountered included lack of baseline data and clear implementation strategies, ineffective environmental sustainability committees, inadequate resource allocation for prescribed activities and lack of information and guidelines. Indicators and indicative measurable variables are proposed. Useful resources to assist in the implementation of the $\mathrm{PC}$ targets are provided. We recommend expansion of the scope of the environmental sustainability PC targets to address the post-2015 global sustainability agenda by aligning them with
\end{abstract}

the Sustainable Development Goals. Private Universities should be also asked to participate in the environmental sustainability performance contracting with the government.

\begin{tabular}{|c|c|c|}
\hline words & Performance & Contracting, \\
\hline Sustainability, & Sustainability & Indicators, \\
\hline
\end{tabular}

\section{Introduction}

Performance Contracting (PC) targets for Environmental Sustainability for Kenyan Public Universities were introduced in the 2012/2013 financial year as a part of the broader public sector reforms for all Ministries, Departments and Agencies (MDAs). Performance contracting was introduced as a strategy for performance improvement in the public service [1]. The objective of performance contracting is "to ensure that performance is measured using international best practices and that performance targets are grown to the extent of placing the country on the cutting edge of global competitiveness". Institutions are expected to ensure that performance indicators are appropriately aligned with the MDAs priority programs and approved budgets [2]. Tertiary institutions are required to submit quarterly performance reports to the government for the purposes of monitoring progress of performance, and for annual evaluation of performance. Environmental sustainability reporting is done through the National Environment Management Authority (NEMA) which provides guidelines to universities on environmental sustainability targets in each annual cycle. The Authority also analyzes the submitted reports and gives feedback to the reporting institutions and the Ministry of Devolution and National Planning.

The performance criteria consist of seven broad areas each with several sub-categories. Environmental sustainability is a sub-category within the "Non-financial category" of the performance criteria. 
The universities and other MDAs were required to select four out of eight environmental sustainability targets for implementation during the annual PC cycles. The focal areas for the two financial years from June 2012 to July 2014 and the output/indicators are shown in Table $1[3,4]$. The ninth target in the NEMA list was on management of waste in counties, urban, townships and market centers which was not relevant to the mandate of the universities and hence is omitted in Table 1.

The government through NEMA prescribed the activities for each focal area and the indicators for verifying the degree of achievement of each target. Although a good start to encourage universities to embrace sustainability initiatives, the proposed indicators (Table 1) were rather general but more importantly, it was not clear how incremental environmental outcomes would be achieved. In other cases, like in the sustainable management of waste, the universities were required to install waste segregation bins. This requirement is in line with best practice but it needs to be supported by requisite policy and resource recovery and recycling infrastructure, which is underdeveloped in the country.

In the 2014/15 financial year, the universities were required to audit their compliance with the Environmental Management and Coordination Act (EMCA) of 1999). An audit checklist was developed covering six broad focal areas each with the key indicators [5]. The focal areas included environmental sustainability planning, pollution control, climate change mitigation and adaptation, environmental and ecological enhancement, environmental education and awareness and, promoting environmental protection and conservation through partnerships with stakeholders. These focal areas are not substantially different from those in Table 1. The difference is that the requirement for the third year was to perform a compliance audit.

Since the introduction of the environmental sustainability performance contract targets for the universities in Kenya, no evaluation has been conducted to assess performance improvement and impact. The objectives of this study were to: conduct a review and analysis of the PC targets reporting by universities; assess the authenticity of reporting; establish key challenges in mainstreaming environmental sustainability recommendations; develop an indicative list of environmental sustainability indicators and, propose resources to guide the universities during implementation of environmental sustainability activities and reporting.

Table 1. Environmental sustainability focal areas (2012/13-2013/14)

\begin{tabular}{|c|c|c|}
\hline Focal area & Indicators & Expected outcomes \\
\hline $\begin{array}{c}\text { Domesticating the environmental policy at the } \\
\text { workplace }\end{array}$ & $\begin{array}{l}\text { - } \begin{array}{l}\text { Approved Internal environmental policy and } \\
\text { implementation plan }\end{array} \\
\text { - } \quad \text { Implementation of the environment policy and } \\
\text { plan -Quarterly reports }\end{array}$ & $\begin{array}{l}\text { Mainstreaming of environmental } \\
\text { sustainability in MDA's activities }\end{array}$ \\
\hline $\begin{array}{l}\text { Developing and implementing environmental } \\
\text { awareness programs }\end{array}$ & - $\quad$ No. of staff sensitized & $\begin{array}{c}\text { Increasing awareness and participation } \\
\text { of staff in environmental conservation } \\
\text { initiatives }\end{array}$ \\
\hline Waste management initiatives & $\begin{array}{l}\text { - } \quad \text { Segregated bins in place and in use } \\
\text { - } \quad \begin{array}{l}\text { Disposal of waste as per the waste } \\
\text { management regulations } \\
\text { - } \\
\text { Evaluation criteria incorporating green } \\
\text { purchases in the evaluation }\end{array} \\
\end{array}$ & Sustainable management of waste \\
\hline $\begin{array}{l}\text { Measures to mitigate all forms of pollution } \\
\text { (water, air, noise) }\end{array}$ & 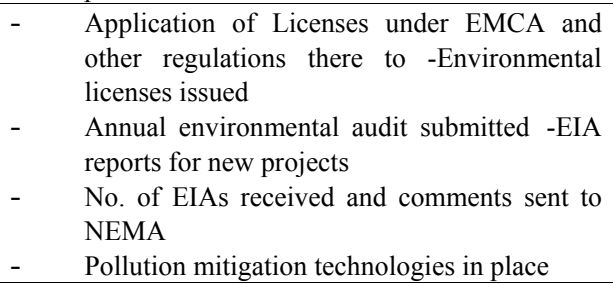 & $\begin{array}{l}\text { The environment protected and } \\
\text { conserved }\end{array}$ \\
\hline $\begin{array}{l}\text { Developing and implementing climate change } \\
\text { mitigation and adaptation initiatives e.g. energy } \\
\text { saving, water harvesting }\end{array}$ & $\begin{array}{ll}\text { - } & \text { Low energy consumption devices in place } \\
\text {-Rain water harvesting structures in place } \\
\text { - } & \text { Use of rainwater for cleaning and watering } \\
\text { - } & \text { Alternative sources of green energy in place }\end{array}$ & $\begin{array}{l}\text { Reduced impacts of MDAs on climate } \\
\text { change }\end{array}$ \\
\hline Planting trees & $\begin{array}{l}\text { No of trees planted, species, and location of the site } \\
\text {-Survival rate in } \%\end{array}$ & Increased forest cover \\
\hline $\begin{array}{c}\text { Protection of river banks by enforcing riparian } \\
\text { regulations }\end{array}$ & $\begin{array}{l}\text { Length or area restored, secured and conserved in } \mathrm{Km} \\
\text { or Ha. }\end{array}$ & $\begin{array}{c}\text { Riverbanks and riparian areas restored } \\
\text { and protected and conserved }\end{array}$ \\
\hline $\begin{array}{l}\text { Promoting environmental protection and } \\
\text { conservation through partnership with } \\
\text { stakeholders }\end{array}$ & $\begin{array}{ll}\text { - } & \text { No. of projects and activities undertaken in } \\
\text { partnership } \\
\text { - No. of Corporate Social Responsibility } \\
\text { activities on Environment }\end{array}$ & $\begin{array}{l}\text { Enhanced protection and conservation } \\
\text { of the environment }\end{array}$ \\
\hline
\end{tabular}




\section{Materials and Methods}

A case study research design was used to track and evaluate the mainstreaming of environmental sustainability targets with the institutional operations of 22 public universities in Kenya for the three years since the introduction of performance contracting. Private universities were not included since they were not participating in performance contracting with the government. Data and information for the environmental sustainability reporting was obtained from the quarterly reports submitted to the National Environment Management Authority between 2012 and 2015. It was assumed that all reports submitted to the Authority were made available for this study. A reporting matrix was developed in which the reporting frequency by year and target were developed from the submitted quarterly reports. Email correspondence or telephone calls were made to some universities to confirm authenticity of the reported activities. Authenticity and ownership of the activities and reported outcomes were checked from the submitted reports. The assumption was that it was highly unlikely for falsified reports to be made when the accounting officer in all cases were the vice-chancellors. Appropriate environmental sustainability indicators were developed from three main sources. The first source was the NEMA guidelines for the three years covered in this study. The second source used was published material in the form of books and journal papers. UNEP's [6] toolkit was particularly useful. Thirdly, online resources on "best practices" from leading universities and colleges were used. Care was taken to develop and propose realistic indicators that the universities can successfully undertake given the priorities and resources at their disposal.

\section{Results and Discussion}

\subsection{Number of Universities Reporting}

The number of universities which submitted quarterly reports on environmental sustainability to NEMA between July 2012 and June 2015 is shown in Table 2.

Table 2. Response rate for submission of quarterly reports

\begin{tabular}{|c|c|c|c|c|c|c|}
\hline \multirow{2}{*}{ Quarter } & \multicolumn{2}{|c|}{$2012 / 13$} & \multicolumn{2}{c|}{$2013 / 14$} & \multicolumn{2}{c|}{$2014 / 15$} \\
\cline { 2 - 7 } & No. & $\%$ & No. & $\%$ & No. & $\%$ \\
\hline 1 & 10 & 45.4 & 19 & 86.4 & 8 & 36.4 \\
\hline 2 & 15 & 68.2 & 16 & 72.7 & 10 & 45.4 \\
\hline 3 & 14 & 63.6 & 17 & 77.3 & 9 & 40.9 \\
\hline 4 & 14 & 63.6 & 14 & 63.6 & 12 & 54.5 \\
\hline Average & & 60.2 & & 75.0 & & 44.3 \\
\hline
\end{tabular}

The expected quarterly reports for each quarter was 22 .
The average proportion (or response rate) of universities submitting the quarterly reports was $60.2 \%, 75.0 \%$ and $44.3 \&$ in 2012, 2013 and 2014 respectively (Table 2). We could not establish the reasons for the very low response rate for the 2014/15 financial year despite the prestigious rankings of ministries, departments and agencies by the government each year. The rather low response rates could be due to financial limitations as the universities do not get additional funding to initiate and maintain environmental sustainability initiatives. There could also be capacity gaps especially in the area of information and guidelines.

Tree planting was the most popular target (72.7\%) followed by domesticating the environmental policy at the work place and developing and implementing environmental awareness programs (63.6\% each) (Table 3). The target on promoting environmental protection and conservation through partnerships with stakeholders occupied a third position (45.4\%). Close to 260,000 trees were planted during the three-year reporting period. However, very few universities reported the reasons for their tree planting activities, tree species planted or the area planted and importantly, the survival rates of planted trees. Theft of tree seedlings by local communities, destruction of seedlings by livestock and inadequate rains were some of the challenges reported by the universities. This suggests that most universities most likely did not allocate adequate resources for post-planting activities and cooperation with local communities to ensure survival of the planted trees. Environmental awareness creation was carried on and off campus through activities such as environmental clean-ups. In many cases, this was a student-led activity which should be encouraged and supported for its experiential learning value to the young generation of environmental stewards.

Table 3. Choice of targets to implement

\begin{tabular}{|c|c|c|}
\hline Target & Frequency & $\%$ \\
\hline Planting trees & 16 & 72.7 \\
\hline Environmental policy & 14 & 63.6 \\
\hline Environmental awareness & 14 & 63.6 \\
\hline $\begin{array}{c}\text { Working with stakeholders to protect and } \\
\text { conserve the environment }\end{array}$ & 10 & 45.4 \\
\hline $\begin{array}{c}\text { Climate change mitigation and adaptation } \\
\text { measures }\end{array}$ & 9 & 40.9 \\
\hline Waste management initiatives & 8 & 36.4 \\
\hline Pollution & 5 & 22.7 \\
\hline Protection of river banks & 4 & 18.2 \\
\hline
\end{tabular}

The last four targets were selected by less than $40 \%$ of the public universities (Table 3). Climate change mitigation and adaptation initiatives involve installation of low energy consumption devices, installation of rainwater harvesting structures and installation of alternative sources of green energy. The likely cost implications in selecting this target could have discouraged most universities. Target on waste management initiatives involved adoption of the 7Rs, 
installation of waste bins and segregation of waste, waste collection by service providers who are licensed by NEMA and procurement of goods and services that are environmentally friendly. Most of the reported activities dealt with solid waste but nothing was done on liquid and gaseous emissions which are quite common in institutions of higher learning. Some of the measures reported to have been undertaken included introduction of waste segregation bins, handling of electrical and electronic waste, and reducing and reusing waste. Waste segregation is an excellent strategy for waste management especially when it is associated with resource recovery and recycling. A proper waste management strategy should ideally be based on the characterization and quantification of the types of waste that an institution generates; however, no university reported such studies. Although it is the right direction to take, some of the required actions for this target are difficult to achieve at the moment for most public institutions, let alone the universities. As indicated in the in Section 1, there is no proper waste management infrastructure to support widespread segregation of waste in Kenya. In respect of measures to mitigate against all forms of pollution (water, air, land and noise), the required actions included acquisition of relevant licenses (to discharge wastes in excess of established environmental standards), submission of annual environmental audits and environmental impact assessment reports, if new projects are undertaken, to NEMA and, installation of pollution mitigation technologies. Several of the requirements in this target are straightforward to undertake. However, installing pollution mitigation strategies could have been assessed as a capital-intensive undertaking, hence discouraging many universities from selecting this target. The last target on protection of riverbanks by enforcing riparian regulations, which has the lowest response rate, must have been difficult to implement most likely due to resource constraints on the part of the universities.

\subsection{Authenticity of Reporting}

The quarterly and annual environmental sustainability reports analyzed for the three-year period were without exception signed by the respective Vice-Chancellors or principals of constituent colleges. Thus, there was ownership of the reported activities and a confirmation that the achievements were made and were genuine. However, there was no evidence of consistency of progressive improvements or follow-up actions on any of the targets chosen. This suggests that the environmental sustainability targets were seen more as discrete targets to be met to satisfy performance contracting obligations with the Government rather than a genuine desire by the Universities to chart a path towards better environmental performance and becoming exemplars of best sustainability practices. Another challenge of the reporting was that the impacts of the various interventions were not assessed and reported on.

\subsection{Challenges Experienced in Mainstreaming Environmental Sustainability Targets}

There were some challenges experienced in mainstreaming the environmental sustainability PC targets in University operations. The targets were seen as PC compliance issues with the government and not for improved environmental performance for the universities. This is supported by the widespread lack of data on baselines, clear implementation strategies, objectives and outcomes. There were challenges in some institutions in the quality of the sustainability committees in terms of their composition and commitment. In some cases, committee members were appointed without regard to their professional background or responsibility in the university operations. In terms of inadequate commitment, this could be attributed to the fact that being a member of such a committee is in most universities an additional responsibility which might conflict with other mandatory staff obligations like teaching and research. Even where funds were available to carry out prioritized activities, there were delays in the release of funds leading to inadequate resource allocation for the prescribed activities. Most appointed environmental sustainability champions and their members had little or no knowledge and professional experience to implement activities prescribed for the focal areas in the Performance Contract Guidelines. Knowledge about relevant national policies, environmental law, regulations, standards and guidelines were inadequate which might explain the lack of appropriate measurement and impacts of various reported activities.

\section{Proposal for Environmental Indicators}

The call for universities to engage in best practices for sustainability planning has increased in the recent years. Transforming universities into green and sustainable campuses [6] is a relatively new concept that the Kenya government and partners are introducing to the universities. Most of the public universities have established environmental sustainability committees to assist in the implementation of the PC targets. However, the challenge remains in translating the targets into tangible actions and, the setting up of indicators that reflect progress towards success. For university managers and these committees, indicators of sustainability are useful tools for setting goals and measuring progress. University or campus sustainability indicators have been developed in a number of leading universities in the developed world. Examples include: The Sustainability Tracking, Assessment \& Rating System (STARS), which was developed by the Association for the Advancement of Sustainability in Higher Education; The Sustainability Competency \& Opportunity Rating \& Evaluation (SCORE) developed by Sustainable Measures; and The College Sustainability Report Card, developed by the Sustainable Endowments Institute in the US among many others. 
Each university in Kenya is unique in terms of its goals and priorities and each exists in a national, regional and local context [6]. The NEMA environmental sustainability guidelines contain an appreciable number of focal areas and rather general indicators and metrics from which the universities are expected to develop an annual work plan to assist in the implementation of priority areas. It therefore seems logical to develop a set of core indicators which are relevant to all universities. These can be supplemented by additional indicators and measurements which a particular university deems worth tracking on its path towards sustainability. However, it is important to point out that selection of sustainability indicators is best done through a participatory process within the university community. The set of indicators outlined below is therefore indicative only.

Indicators and associated measurable results provide a means to monitor progress towards sustainability $[6,7]$. In the various environmental sustainability performance cycles, an attempt has been made to provide performance indicators for each focal area. The selection and definition of the indicators was largely top-down and broadly covered the biophysical aspects of university sustainability (with directly measurable attributes) as well as management indicators (more qualitative). However, the indicators prescribed over the three-year period covered in this paper do not meet all the criteria of an optimal indicator set [6] which include:

- Purposefulness (focused, implementable and meaningful)

- Efficiency (simple, accessible and practical)

- Effectiveness (measurable, relevant, and timely)
- Communicability (clear, transparent and explicit) and

- Responsiveness (adaptable, scalable and replicable).

On the basis of the environmental sustainability performance contracting guidelines and international best practice, the following sustainability indicator set is proposed (Table 4). The indicator set covers eight areas, each with proposed major indicators. Under each major indicator, there can be several sub-indicators. No attempt is made in this paper to provide the metrics required for each indicator, especially for the biophysical aspects of the indicator. However, these can easily be compiled from best practice around the world and appropriately customized to local context.

\section{Resources for Performance Contract Targets and Reporting}

This part of the paper brings together and summarizes a selected number of resources that may assist universities in identifying and defining environmental sustainability indicators as well as implementing work plans, and measuring and reporting progress. It comprises both printed and online resources with respect to national and international university associations, policies, laws and regulations as well as standards/guidelines. The list is by no means exhaustive but rather a living document that should be updated from time to time to keep abreast of rapid changes and growth.

Table 4. Proposed environmental performance indicators for Kenyan universities [after 2, 3, 4 \& 6]

\begin{tabular}{|c|c|}
\hline Focal area & Indicative measurable variables \\
\hline $\begin{array}{c}\text { Sustainability in } \\
\text { research }\end{array}$ & Level of grant funding publications, conferences and seminars, commercialization \\
\hline $\begin{array}{c}\text { Education for } \\
\text { sustainability }\end{array}$ & Cross-disciplinary courses, sustainability literacy, curriculum integration of sustainability concepts and principles \\
\hline $\begin{array}{c}\text { Governance and } \\
\text { administration }\end{array}$ & $\begin{array}{c}\text { Existence of a university sustainability policy, existence of a sustainability management plan, existence of a sustainability } \\
\text { steering committee or equivalent university-wide body that includes the student community, responsibility for oversight of } \\
\text { sustainability matters allocated to members of senior management, appointment of a sustainability manager, orientation } \\
\text { programs on sustainability for students, academic and operational staff, existence of socially responsible purchasing, disposal } \\
\text { and investment practices and policies and regular environmental audits }\end{array}$ \\
\hline $\begin{array}{c}\text { Community } \\
\text { outreach }\end{array}$ & Service learning, collaboration with other institutions, community sustainable development projects \\
\hline $\begin{array}{c}\text { Energy, carbon } \\
\text { and climate change }\end{array}$ & Assessments of operational energy, embodied energy, transport energy, greenhouse gas emissions \\
\hline Water use & Potable water, water reuse, rainwater harvesting \\
\hline Land use & Green buildings, space planning, ecosystem services, biodiversity \\
\hline Material flows & Contract specification and evaluation, supply chain management, life cycle assessment, waste minimization; reduction in air, \\
& \\
\hline
\end{tabular}




\subsection{University Associations}

- Association of African Universities: The Association of African Universities (AAU), whose headquarters is in Accra, Ghana, was founded in 1967. Its mission is to enhance the quality and relevance of higher education in Africa and strengthen its contribution to African development (http://www.aau.org/)

- Global Universities Partnership on Environment and Sustainability (GUPES): GUPES is one of the flagship programmes of UNEP's Environmental Education and Training Unit (EETU). At present, over 800 universities and regional partners/focal points from five different continents are part of the growing GUPES network.

(http://www.unep.org/training/programmes/gupes.as p)

- Southern African Regional Universities Association (SARUA): Founded in 2005, SARUA is a membership-based organization which is open to all the public universities of the 15 countries that make up the Southern African Development Community (SADC). SARUA currently has 57 members. SARUA was established to assist in the revitalization and development of the leadership and institutions of higher education in the southern African region, thus enabling the regional higher education sector to meaningfully respond to the developmental challenges facing the region. http://www.sarua.org/

- Association of West African Universities (AWAU): A sub-regional body Established in 2011, to coordinate and promote the ideals of university education in West Africa with a view to strengthening and developing the leadership of the University Education System in West Africa. http://www.awau.org/

- Inter-University Council for East Africa (IUCEA): The IUCEA was formed in 1980 to facilitate networking among universities in East Africa, and with universities outside the region. http://www.iucea.org/

\subsection{National Policies, Standards and Guidelines}

A number of useful national and county government sustainability policies, standards and guidelines are available in print or electronic form. Although universities are required to comply with the legislative requirements, it is advisable for them to set realistic targets that will ensure compliance and strive even to surpass the legislative requirements. Table 5 contains a number of useful resources. The list is by no means exhaustive and will require updating from time to time.

Table 5. Useful policies, standards and guidelines

\begin{tabular}{|c|c|c|}
\hline No. & Tile & Date issued \\
\hline 1 & Biosafety Act No. 2 & 2009 (Rev. 2012) \\
\hline 2 & County Governments Act No 17 & 2016 \\
\hline 3 & Environmental Management and Coordination (E-waste Management) Regulations & 2013 \\
\hline 4 & Environmental Management and Coordination (Fossil Fuel Emission) Regulations & 2006 \\
\hline 5 & $\begin{array}{l}\text { Environmental Management and Coordination (Noise and Excessive Vibration Pollution } \\
\text { (Control)) Regulations }\end{array}$ & 2009 \\
\hline 6 & National Environmental Policy (Draft) & 2012 \\
\hline 7 & Pest Control Products Act (1985) & Revised 2012 \\
\hline 8 & Physical Planning Act & Revised 2012 \\
\hline 9 & The Public Procurement and Disposal Regulations & 2006 \\
\hline 10 & The Public Procurement and Disposal Act & Revised 2010 \\
\hline 11 & Radiation Protection Act & Revised 2012 \\
\hline 13 & The Constitution of Kenya & 2010 \\
\hline 14 & The Environmental Management and Coordination Act No. 8 & 1999 \\
\hline 15 & The Occupational Safety and Health Act & Revised 2010 \\
\hline 16 & The Environmental Management and Coordination (Controlled Substances) Regulations & 2007 \\
\hline 17 & $\begin{array}{c}\text { The Environmental Management and Coordination (Wetlands, River Banks, Lake Shores and } \\
\text { Sea Shore Management) Regulations }\end{array}$ & 2009 \\
\hline 18 & The Environmental Management and Coordination (Waste Management) Regulations & 2006 \\
\hline 19 & The Environmental Management and Coordination (Water Quality) Regulations & 2006 \\
\hline 20 & Water Act & Revised 2012 \\
\hline
\end{tabular}




\subsection{International Agreements and Declarations}

The concept of sustainability in higher education was first introduced at an international level by the UNESCO-UNEP International Environmental Education Program in 1978 [8]. A number of declarations relating to environmental sustainability in higher education institutions have been developed, endorsed and signed by a number of universities. Below are examples of some of these declarations:

Talloires Declaration: Composed in 1990, this is the first official statement made by university administrators of a commitment to environmental sustainability in higher education. The Talloires Declaration is a ten-point action plan for incorporating sustainability and environmental literacy in teaching, research, operations and outreach at colleges and universities. As of January 2016, total signatory institutions had reached 499 from over 50 countries. The University of Nairobi and Moi University have signed the declaration

(http://www.ulsf.org/programs_talloires_signatories.html\#to p).

The Higher Education Sustainability Initiative (HESI): HESI was created as a partnership of UN entities (UNESCO, UN-DESA, UNEP, Global Compact, and UNU) in the run-up to the United Nations Conference on Sustainable Development $(\mathrm{Rio}+20)$. With a membership of almost 300 universities from around the world, HESI accounts for more than one-third of all the voluntary commitments that came out of Rio +20 (https://sustainabledevelopment.un.org/index .php?menu=1073).

The Nagoya Declaration on Higher Education for Sustainable Development: This was adopted by the participants of the International Conference on Higher Education for Sustainable Development in Nagoya, Japan on 9 November 2014. It reaffirms the responsibility of higher education for pursuing sustainable development and commits their support to further advancing sustainable development through education for sustainable development. Link: http://www.c-linkage.com/for/hesd/declaration.html

\subsection{Books and Journals}

There is a growing body of published literature on practical experience and theoretical development on the sustainability imperatives of organizations such as universities. This literature includes books, journals and considerable on-line resources. The key aides to universities include, among others, the greening universities tool kit developed by UNEP [6] and the book by Brady [9] on environmental management in organizations.

The Journal of Cleaner Production: A trans-disciplinary forum for the exchange of information and research concepts, policies, and technologies designed to help ensure progress towards making societies and regions more sustainable. It aims to encourage innovation and creativity, new and improved products, and the implementation of new, cleaner structures, systems, processes, products and services. It is also designed to stimulate the development and implementation of prevention oriented governmental policies and educational programmes. Cleaner production is a concept that goes beyond simple pollution control. It involves active research and development into new structures, systems, processes, materials and products that are more resource and energy efficient, whilst engaging and empowering people. Such approaches have become necessary for businesses, institutions, governments, and civil society to ensure ecologically, socially, and economically sustainable, consumption production and service strategies. These involve educational, training, management, and technical assistance programs, which are needed to accelerate the adoption of cleaner production and sustainability by industries, governments and universities.

https://www.journals.elsevier.com/journal-of-cleaner-produ ction

Sustainability Science: The journal provides a trans-disciplinary platform for contributing to building sustainability science as a new academic discipline focusing on topics not addressed by conventional disciplines. As a problem-driven discipline, sustainability science is concerned with addressing practical challenges caused by climate change, habitat and biodiversity loss, and poverty among others. At the same time, it tries to investigate root causes of problems by uncovering new knowledge or combining current knowledge from more than one discipline in a holistic way to enhance understanding of sustainability. The journal provides a multidisciplinary forum for communication among researchers, policy makers, practitioners, educators, and the young generation. http://link.springer.com/journal/11625

International Journal of Sustainability in Higher Education: The journal addresses the need for documentation and the dissemination of research, studies and projects on sustainability matters among higher education institutions. It provides information on new developments and trends, and provides a platform for networking and information exchange on a global basis. http://www.emeraldgrouppublishing.com/products/journals/ journals.htm? $\mathrm{id}=\mathrm{ijshe}$

\subsection{Online Tools and Resources}

There is a growing list of online resources to assist universities to implement and measure progress in sustainability programs and projects. They include self-assessment reporting frameworks and questionnaires, guidelines and case studies [6]. Most university associations (e.g. AASHE) provide some of the best practice case studies and checklists for reference [6]. The list below gives a brief description of some of the well-known tools and the links for more information: 
- Charter \& Guidelines which was developed by the International Sustainable Campus Network (ISCN). The Charter was developed to support universities in setting targets and reporting on sustainable campus development goals and performance against the three principles of the ISCN which include (1) buildings and their sustainability impacts, (2) campus-wide planning and target setting, and (3) integration of research, teaching, facilities and outreach (http://www.international-sustainable-campus-netwo rk.org/charter-and-guidelines)

- Sustainability Tracking and Rating System (AASHE STARS): STARS This was developed by the Association for the Advancement of Sustainability in Higher Education. It is a transparent, self-reporting framework for colleges and universities to measure their sustainability performance. The tool is designed to: provide a framework for understanding sustainability in all sectors of higher education, enable meaningful comparisons over time and across institutions using a common set of measurements developed with broad participation from the international campus sustainability community, create incentives for continual improvement toward sustainability, facilitate information sharing about higher education sustainability practices and performance and, build a stronger, more diverse campus sustainability community.

https://stars.aashe.org/pages/about/stars-overview. html

- The Sustainability Assessment Questionnaire (SAQ) is designed to assist in assessing the extent to which the college or university is sustainable in its teaching, research, operations and outreach. "Sustainability" implies that the major activities on campus are ecologically sound, socially just, economically viable and humane, and that they will continue to be so for future generations.

http://www.ulsf.org/pdf/SAQforHigherEd09.pdf

- Sustainable Development on Campus: Tools for Campus Decision Makers: These tools will help decision makers at universities learn more about sustainable development and "green" campuses. There are learning modules, case studies, action plans, environmental policies, resources, forums and contacts intended to help administrators, students, or faculty members implement sustainable development on their campuses. Topics include declarations of commitment to sustainable development by academic leaders, a review of sustainable development and ideas for integrating them into curricula and practices, and sample policies for implementing sustainable development http://www.iisd.org/educate/
- Teaching and Learning for a Sustainable Future (A UNESCO site): This is a multimedia, interactive professional development program with materials, exercises, and links that help educators deepen their understanding of education for sustainability and its importance in addressing the economic, social, and environmental issues of the world. This site presents key educational issues that form the rationale for Education for a Sustainable Future (ESF), including: A basic understanding of sustainable development; help in understanding the range of social, economic, and environmental issues facing the world today; the interrelationships among these different types of issues; and the ways that education is key to the empowerment of people working for a sustainable future; The site also includes "Future studies," which explore different ideas and perspectives about the future and include exercises designed to examine personal views as well as writings by futurists, consider probably versus preferable future scenarios, and incorporate these ideas into the curriculum; and various strategies for the education community to reorient education toward the broader process of building a sustainable future.

http://www.esdtoolkit.org/resources/web_esd.htm

- Campus Sustainability Toolkit: This tool was developed by the International Alliance of Research Universities (IARU) in 2009 with the aim of promoting collaboration between member institutions, and developing best practice strategies in environmental management. This toolkit is based on the experiences of the IARU members in creating and maintaining a sustainable campus. This toolkit is especially useful for universities that are beginning their sustainability journey. Most importantly, it highlights the importance of active participation of staff and students for the achievement of sustainability goals.

(http://www.iaruni.org/sustainability/campus-sustain ability)

The objectives of this study were to conduct a review and analysis of the PC targets reporting by universities; assess the authenticity of reporting; establish key challenges in mainstreaming environmental sustainability recommendations; develop an indicative list of environmental sustainability indicators and, propose resources to guide the universities during implementation of environmental sustainability activities and reporting. The first objective dealing with analysis and PC targets reporting was addressed using data and information for the three years from $2012 / 13$ to $2014 / 15$ as shown in Section 3.1. The second objective on authenticity of reporting was achieved via the analysis of all the reports to establish ownership by top management as well as contacting some universities for confirmation of certain activities. The third objective was 
achieved through analysis of the submitted reports which had a provision for explaining the reasons for variance between targets and what each university achieved in a particular reporting cycle. In the last few years, a number of universities particularly in the developed world, international organizations such as UNEP, industry and business organizations have developed and tested environmental sustainability indicators and useful resource guides. These diverse sources well helpful in the realization of the last two objectives as elaborated in Sections 4 and 5, respectively.

\section{Conclusions}

The environmental sustainability PC targets have so far targeted public universities yet, Kenya has a good number of private universities some of which are undertaking sustainability initiatives. The sustainability targets so far appear to be requirements by the government rather that a genuine desire by the universities to reduce their ecological footprint and to be examples to internal and external communities as leaders in sustainability initiatives. The sustainability committees are not effective in their mandate perhaps due to their selection and motivation, as well as lack of information and guidelines. It is also clear that few universities have a budget line for environmental sustainability initiatives. Most universities lack baselines and continuity of initiated activities. Hence, the impacts of these activities are difficult to assess and report on. The level of involvement of students and other stakeholders is weak in almost all universities. It is also evident that there is lack of common metrics for measuring progress and for facilitating comparison

To encourage and empower universities to play their role in sustainability planning the universities that do not have an environmental sustainability policy and a well constituted committee to oversee its implementation should do so. Private universities in Kenya should also join the public universities in implementing and reporting on the PC environmental sustainability targets. It is recommended that they should be recruited into the newly established Kenya Green Universities Network.

Finally, the universities should become more proactive and expand the scope of the prescribed environmental sustainability targets in order to strategically address the post-2015 global sustainability agenda by aligning their commitments and activities with the Sustainable Development Goals.

\section{Acknowledgements}

The author acknowledges UNEP for funding this study.
The paper was finalized while the author was on sabbatical leave at the Graduate Programme in Sustainability Science-Global Leadership Initiative (GPSS-GLI) at the University of Tokyo. The financial support to publish the paper by the University of Tokyo is gratefully acknowledged. The National Environment Management Authority allowed access to the data used to develop this paper. Comments to an earlier draft of this paper by Jaime Webbe of the Environmental Education and Training Unit at UNEP are gratefully acknowledged. The helpful comments by an anonymous reviewer are much appreciated. Finally, the author acknowledges the support by Jeanne Njeri in data analysis.

\section{REFERENCES}

[1] Kobia, M. and Mohammed, N., 2006. The Kenyan experience with performance contracting. Paper presented at the $28^{\text {th }}$ African Association for Public Administration and Management Annual Roundtable Conference, Arusha, Tanzania.

[2] Republic of Kenya, 2014. Performance Contracting Guidelines for the Financial Year 2014/15, $11^{\text {th }}$ Edition.

[3] National Environment Management Authority, 2012. Environmental sustainability performance contract targets for ministries, departments and agencies (MDAS) for 2012/13 financial year, NEMA, Nairobi.

[4] National Environment Management Authority, 2013. Environmental sustainability performance contract targets for ministries, departments and agencies (MDAS) for 2013/14 financial year, NEMA, Nairobi.

[5] National Environment Management Authority, 2014. Environmental sustainability performance contract targets for ministries, departments and agencies (MDAS) for 2014/15 financial year, NEMA, Nairobi.

[6] UNEP 2014. Greening universities toolkit v2.0 - Transforming universities into green and sustainable campuses: a toolkit for implementers.

[7] Sustainable Cities International, 2012. Indicators for sustainability: How cities are monitoring and evaluating their success.

[8] Wright, T., 2004. The Evolution of Environmental Sustainability in Higher Education, In: Corcoran, P.B. and A.E. J. Wals, 20014. Higher Education and the Challenge of Sustainability: Problematics, Promise and Practice.

[9] Brady, J., 2006: Environmental Management in Organizations: The IEMA Handbook. Earthscan, London. Government of Kenya, 2015. Draft national energy and petroleum policy. Ministry of Energy and Petroleum. 